\title{
Development of a Pilot-scale Biomass Refinery System for Suburban Agricultural and Livestock Industrial
} Areas

\author{
Yoshito YUYAMA*, Masato NAKAMURA and Masaru YAMAOKA \\ Research Team for Biomass Recycling System, Department of Rural Technologies, National Institute \\ for Rural Engineering, National Agriculture and Food Research Organization \\ (Tsukuba, Ibaraki 305-8609, Japan)
}

\begin{abstract}
We have implemented research programs to demonstrate a biomass refinery system for suburban agricultural and livestock industrial areas. We developed a model targeting the Yamada area in Katori City, Chiba Prefecture. The main feedstock biomasses were cow wastes, food processing residues, woody biomass and non-edible portions of farming crops. Elemental technologies such as methane fermentation, gas refining, co-generation, carbonization, concentration of digested liquid, steam explosion, and composting were combined to efficiently produce useful materials and energy, and to minimize both the input of fossil energy to operate elements of plants/units/equipment and the negative impacts of biomass use on the environment. We succeeded in systematic operation of the plants. The biogas produced was refined to methane gas with a concentration greater than $98 \%$. More than $90 \%$ of the methane gas from the biogas was collected. It was used as fuel sources for carbonization, co-generation and vehicles to transport biomass. The produced digested liquid was widely used. Systemization of biomass production, collection, transportation, storage, conversion, and use of the converted biomass-derived materials/energy is essential. Achievements of the study provide a pioneering model for local governments all over Japan and other Asian countries to construct biomass towns employing local creativity and ingenuity.
\end{abstract}

Discipline: Watershed and regional resources management

Additional key words: bio-liquid fertilizer, biomass town, cow wastes, methane fermentation, methane vehicle

\section{Introduction}

Japan is relatively rich in biomass resources owing to a calm climate and plenty of rainfall. However, the biomass has not been efficiently used recently because of low recognition as a resource, low density in distribution, difficulty of handling due to high water content and large volume, difficulty of collection, low efficiency in the conversion process, and low profitability as a business project.

Adequate biomass use can contribute to energy saving and mitigation of environmental problems. Promotion of biomass use is worthy because of its properties such as being 1) renewable, 2) storable, 3) alternative, 4) abundant, and 5) carbon neutral. Figure 1 shows an image of circulative use of biomass resources. Adequate disposal should be taken into account.

The Government of Japan created the "Biomass Nippon strategy" at a Cabinet meeting on $27^{\text {th }}$ December 2002. It was revised on $31^{\text {st }}$ March $2006^{1}$. They showed the background, goals and strategies to promote the use of biomass resources. The four fundamental concepts in the strategy are 1) prevention of global warming, 2) creation of a recyclingoriented society, 3) fostering of new strategic industries with competitive edges, and 4) activation of agriculture and forestry, as well as associated rural communities.

In terms of the development of technologies, a "biomass refinery" system ${ }^{3}$ in which various useful materials and fuels are systematically produced from biomass that has been generated locally was identified as one of the top priorities.

This paper reports the results obtained in the projects of "Study on Biorecycling of Wastes from Agriculture, Forestry and Fisheries Sector (Bio-recycle)" and "Rural Biomass Research Project, Biomass Utilization Model-Cm3000 (Biomass utilization model)" sponsored by the Ministry of Agriculture, Forestry and Fisheries (MAFF) of Japan.

*Corresponding author: e-mail yuya@affrc.go.jp

Received 20 October 2008; accepted 10 April 2009. 


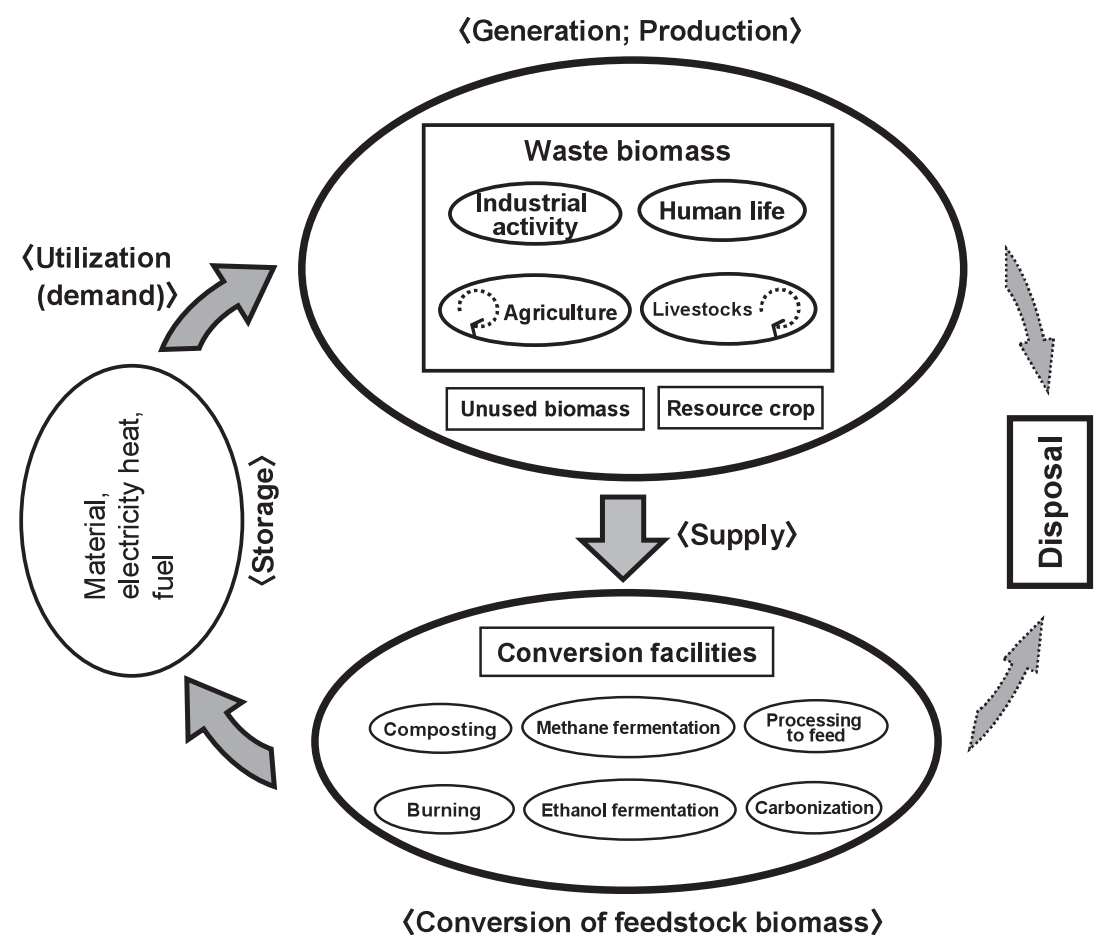

Fig. 1. Circulative use of biomass resources

It is because Japan requires high efficiency in conversion under the limited environmental capacity and the regional variety of biomass generation/production.

This system is realized by cascade use and repetitive use of renewable biomass resources. The produced products such as biomass-derived plastics and fuels such as methane and bio-ethanol can partially replace the functions of fossil fuels.

The spatial scale of biomass utilization must be small, taking into account limitations in transportation and social/ institutional aspects. The community unit utilizing biomass that fits the above mentioned demands and necessities can be called a "biomass town". A biomass town should be designed in totality considering 1) biomass generating points, their distribution and quantity, 2) transportation system, 3) storage of feedstock biomass and biomass-derived products/energy, 4) process of conversion, 5) demand and market of biomassderived products/energy, and 6) contribution to saving fossil energy and the environment. The sustainability of agriculture and forestry as a basis of biomass production, as well as social infrastructures are prerequisite conditions to realize the biomass town.

Based on the above background, we have implemented research programs to demonstrate one type of biomass refinery system. This paper introduces the significance of a biomass refinery and biomass town, the purpose and outline of research programs and their achievements.

\section{Purpose and outline of research programs}

\section{Purpose of research programs}

Our final goal is to develop a sound material-cycle society by appropriate use of biomass resources. It will contribute to the conservation of the environment, and activation of the rural community and agriculture.

In this study, we aim to develop and demonstrate a model of the biomass refinery system for suburban agricultural and livestock industrial areas, targeting the Yamada area in Katori City, Chiba Prefecture. A scheme will be created, operational organizations will be founded, various legal procedures will be conducted, a group of experimental biomass conversion plants will be designed, manufactured and installed, the plants will be operated to test their performance, the material balance and the energy balance will be analyzed, and the environmental impact will be investigated. Then, the effectiveness and problems of the system will be clarified.

\section{Study area}

The Yamada area has a population of 11,000 and farmland of 2,400 ha. Livestock raising is a prosperous industry in the area. The annual biomass resources generated are approximately 200 thousand tons wet weight. Livestock wastes occupy $92 \%$ of the total. Others are $3 \%$ of 
non-edible vegetable parts, $3 \%$ of rice straw, $1 \%$ of rice husk etc. Efficient and circulative ways to use the biomass were needed and in fact were under consideration when we started the research program ${ }^{4}$.

\section{Outline of research programs}

We have promoted the study by following two research projects:

\section{(1) Bio-recycle project}

The title of the research program is "A study on modeling and demonstration of a cascade use system of biomass in northeastern Chiba Prefecture"2-5. The first task was to construct a regional model combining several technologies for the collection/transportation, conversion and utilization of biomass resources. This task was carried out based on statistical data collection, field survey and computer simulation of the material/energy balance analysis. The second task was to verify the model through design, trial manufacturing, installation, operation and capacity tests of pilot-scale plants, and investigation of the environmental impacts. The third task was practical use examination of the materials and energy produced in the plants. The research period was three years from June 2004 to March 2007.

\section{(2) Biomass utilization model project}

The title of the research program is "Development, demonstration and evaluation of biomass use model for Kanto suburban agricultural area"6. The program was designed based on the former program of the Bio-recycle project. The present concrete task is to show the scenario of the biomass use system that enables a reduction in lifecycle costs and lifecycle fossil energy consumption by $20 \%$. The research period would be five years from June 2007 to March 2012.

\section{Results and discussion}

\section{Basic design of Yamada Biomass Plant}

Based on diagnosis of the flow of biomass resources in the Yamada area, the biomass refinery system for this area was designed. We named this combination of experimental plant/unit/equipment as the "Yamada Biomass Plant" (hereafter referred to as YBP). The scale of the YBP was a pilot-scale setting of approximately one hundredth of the potential maximum amount for biomass generation in the Yamada area. Figure 2 shows the main components of the system. The rectangular red backgrounds with outline characters show the feedstock biomass. The rectangular red frames show the conversion plants/units/equipment. The elliptic and curved figures show the converted material/ energy. The yellowish green arrows show input of feedstock biomass. The black and brown solid line arrows show the flow of material and energy, respectively. The dotted line arrows show the designed flow without demonstration.

The feedstock biomass resources for the YBP are cow wastes, food processing residues, woody biomass, and non-edible portions of farming crops. Elemental technologies to produce useful material products and energy, such as methane fermentation, gas refining, co-generation, carbonization, concentration of digested liquid, physicalchemical treatment by steam explosion, and composting were combined appropriately to minimize the input of fossil energy to operate the plant including transportation of biomass.

The main elements of plants/units/equipment ${ }^{2}$ of the YBP were designed as follows:

(1) Biogas plant (methane fermentation): This plant produces biogas containing about $60 \%$ methane and digested liquid from the cow wastes and food processing residues (vegetable juice). A moderate-temperature-type methane fermentation system operated at $37^{\circ} \mathrm{C}$ is employed. The retention time of feedstock biomass in the methane fermentation tank is for 27 days.

(2) Methane fuel producing unit (gas refining): This unit purifies the biogas produced in the biogas plant up to more than $98 \%$ methane. The PSA (pressure swinging adsorption) process is employed. The gas is stored in an adsorptive storage tank filled with adsorbent (activated carbon) at a pressure of 0.6 $\mathrm{MPa}$. The refined methane gas is used as fuel sources for carbonization, cogeneration and methane vehicles.

(3) Methane vehicles: Three types of vehicles driven by methane gas are manufactured. The lightweight pickup truck is used to transport the biomass feedstock and products in the region. The fork lift and yard operation vehicle are also used to transport biomass in the YBP.

(4) Co-generation: The electricity and heat are produced by a $25 \mathrm{~kW}$ engine. The fuel is the $98 \%$ methane. The produced heat is used to raise the temperature of the biogas plant.

(5) Super-heated steam carbonization plants: One plant produces solid fuel (charcoal) from the half-dried solid residues. The carbonization temperature is $350-600^{\circ} \mathrm{C}$. The solid fuel is mainly used at another carbonization plant. This plant carbonizes woody biomass by superheated steam at 300-400 degrees centigrade. It is operated under atmospheric pressure and nearly oxygen-free conditions. Industrial biochemicals, such as wood vinegar and essential oils, are produced. This plant also works as a biomass boiler.

(6) Digested liquid concentration unit: This unit separates the digested liquid into the solid and liquid phases by coagulation, and then concentrates the liquid phase to a value-added bio-liquid fertilizer. An RO (reverse osmosis) membrane is used at first. Secondarily, vacuum 


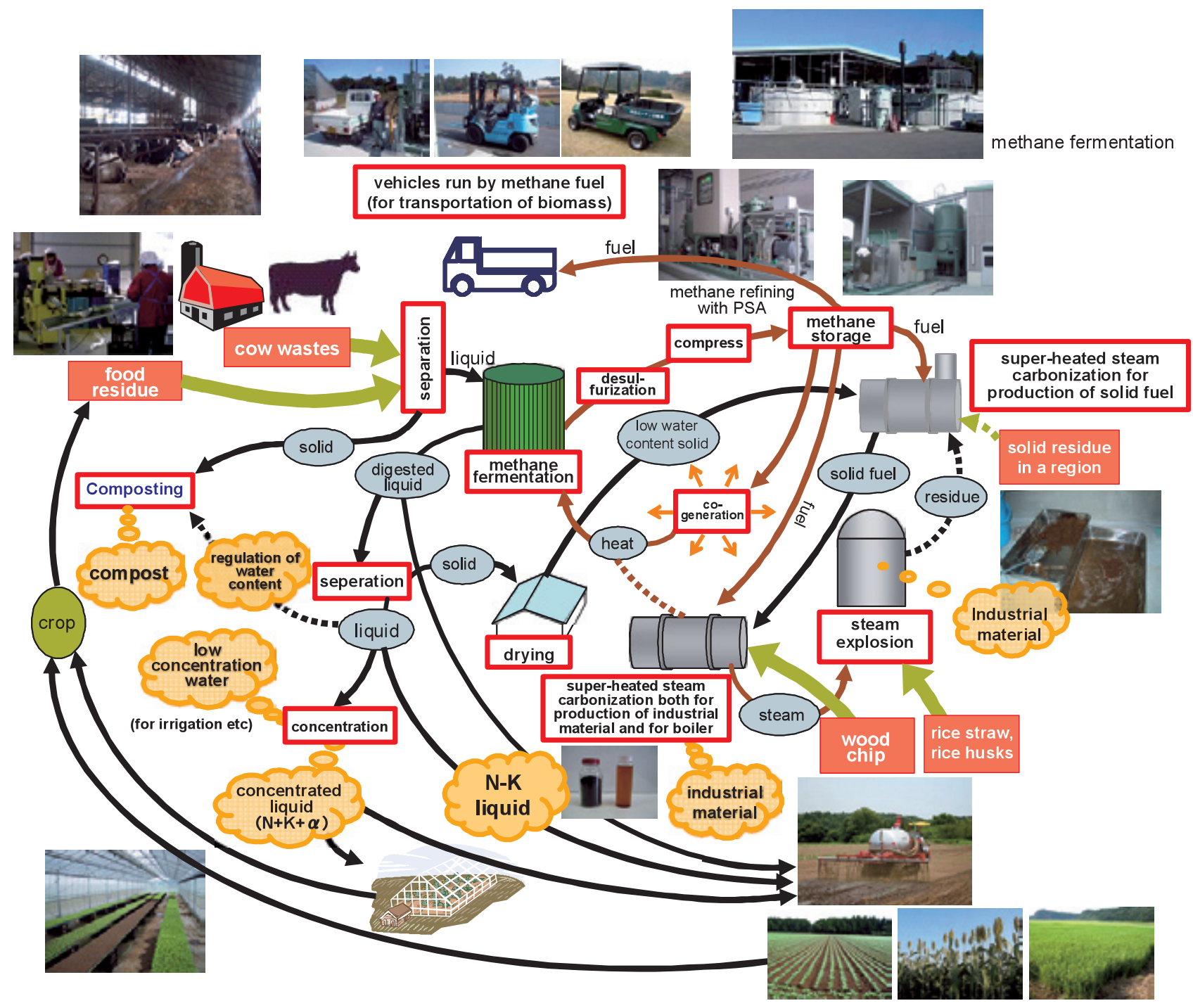

Fig. 2. Model of biomass refinery system for suburban agricultural and livestock industrial areas

distillation is applied.

(7) Steam explosion equipment: This equipment produces industrial biochemicals such as sugars, furfurals and water-soluble silicates, from woody biomass, rice straw and rice husks. These raw materials are chemically treated by steam at a temperature of $200-250^{\circ} \mathrm{C}$ under saturated vapor pressure. When the pressure of the autoclave is released momentarily, the cell membranes of the biomass are destroyed with the adiabatic expansion of the pressurized steam. The steam produced by the biomass boiler is used.

\section{Performance of the Yamada Biomass Plant}

Most of the legal procedures and regulations to install and operate the YBP were completed by June 2005. The operation of the biogas plant began from July 2005. The YBP was officially opened on $1^{\text {st }}$ November 2005. Mr.
Kunio Abe was required to be Director of the YBP.

We succeeded in systematic operation of the plants/ units/equipment, and produced methane gas as fuel, digested liquid, industrial raw materials, etc. Approximately $65 \mathrm{Nm}^{3}$ /d of methane gas refined to $98 \%$ or more was produced as designed by inputting $5 \mathrm{t} / \mathrm{d}$ of liquid phase feedstock biomass into the methane fermentation tank. More than $90 \%$ of the methane from the biogas was collected ${ }^{2}$. However, the methane production rate was usually lower because cow wastes contained many impurities such as sawdust. Actually, average methane production when we operated the PSA between April and October, 2007 was $46 \mathrm{Nm}^{3} / \mathrm{d}$. We could use the refined methane gas as fuel sources for carbonization, co-generation and methane vehicles including a pickup truck, forklift and yard operation vehicle. The latter two vehicles were equipped with absorptive fuel tanks for methane gas. The truck could run approximately $20 \mathrm{~km}$ on 1 
$\mathrm{Nm}^{3}$ of the refined methane. The digested liquid was widely used as a bio-liquid fertilizer and part of it was concentrated to reduce the volume.

Table 1 shows the material balance at the biogas plant. The solid substance is generated by pre-treatment for solidliquid separation. The solid phase becomes feedstock for composting. The liquid phase is substantial feedstock for methane fermentation. The input and product items except for weight in Table 1 did not match in the totals because of sampling problems and emissions from the storage tank for digested liquid. The ratios of carbon in products except for solid substances are $35 \%$ of methane, $26 \%$ of carbon dioxide and $39 \%$ of digested liquid. Table 1 indicates the importance of pre-treatment in methane fermentation. Where and who should carry out solid-liquid separation of the feedstock biomass would be an important consideration.

Figure 3 shows the daily quantity of power generation, purchased electricity and electricity consumption by several

Table 1. Amount of input and products at biogas plant (April - October, 2007)

\begin{tabular}{|c|c|c|c|c|c|c|}
\hline & & $\begin{array}{c}\mathrm{C} \\
(\mathrm{kg} / \mathrm{d})\end{array}$ & $\begin{array}{c}\mathrm{N} \\
(\mathrm{kg} / \mathrm{d})\end{array}$ & $\begin{array}{c}P \\
(\mathrm{~kg} / \mathrm{d})\end{array}$ & $\begin{array}{c}\mathrm{K} \\
(\mathrm{kg} / \mathrm{d})\end{array}$ & $\begin{array}{l}\text { Weight } \\
(\mathrm{t} / \mathrm{d})\end{array}$ \\
\hline \multirow{4}{*}{ 节 } & Cow wastes & 193.44 & 9.84 & 2.99 & 11.19 & 2.47 \\
\hline & Squeezed cow wastes & 22.33 & 4.56 & 1.14 & 4.21 & 1.64 \\
\hline & Vegetable juice & 12.95 & 1.03 & 0.17 & 1.88 & 0.69 \\
\hline & Total & 228.72 & 15.43 & 4.31 & 17.28 & 4.80 \\
\hline \multirow{5}{*}{$\begin{array}{l}\frac{n}{0} \\
0 \\
0 \\
0 \\
0\end{array}$} & Solid substances & 104.33 & 3.26 & 1.11 & 2.14 & 0.72 \\
\hline & $\mathrm{CH}_{4}$ & 29.32 & 0.0 & 0.0 & 0.0 & 0.04 \\
\hline & $\mathrm{CO}_{2}$ & 21.27 & 0.0 & 0.0 & 0.0 & 0.08 \\
\hline & Digested liquid & 32.25 & 12.80 & 2.24 & 13.02 & 3.97 \\
\hline & Total & 187.18 & 16.06 & 3.35 & 15.16 & 4.80 \\
\hline
\end{tabular}

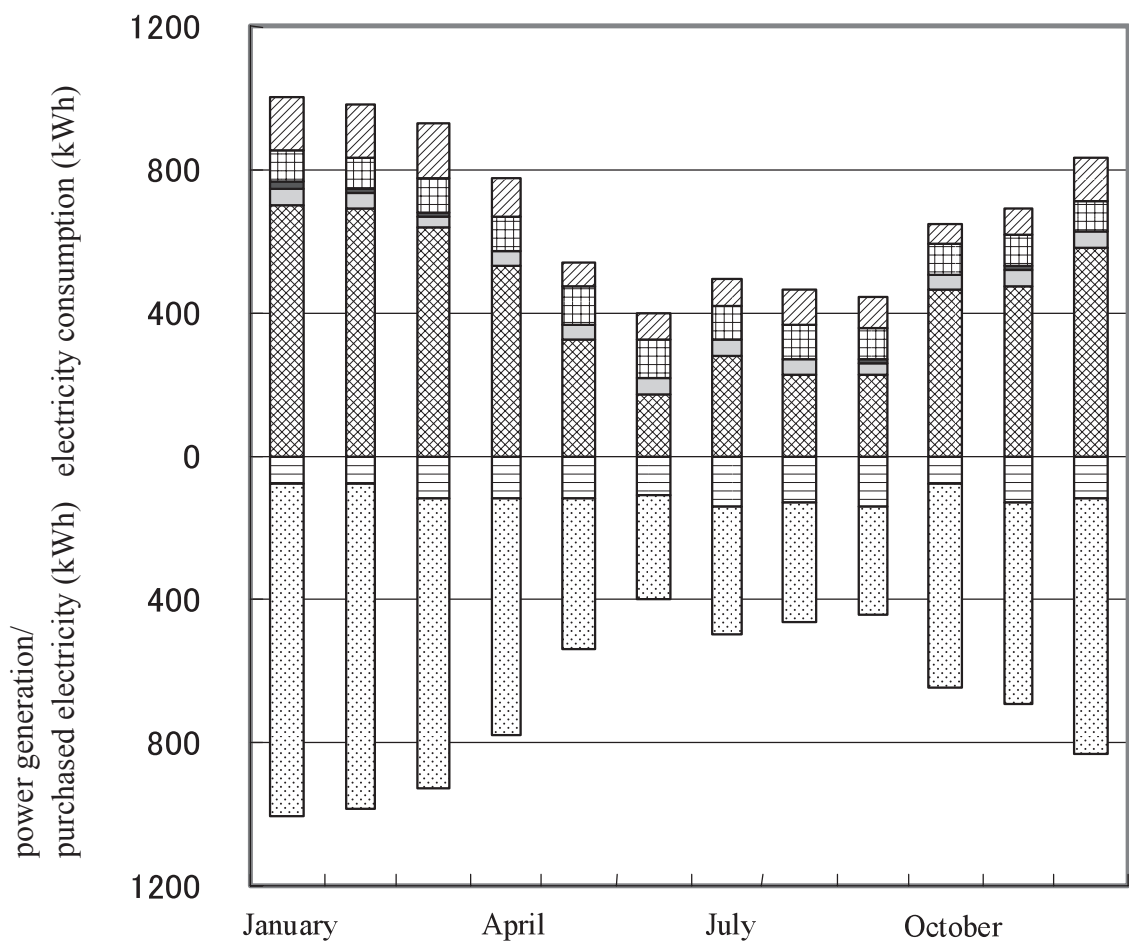

Fig. 3. Daily quantity of power generation, purchased electricity and electricity consumption by several devices (January - December, 2007)
$\square$ others,
田 PSA,
solid-liquid separation,
methane fermentation (except heating),
冈 heating of methane
purchased electricity,
$\boxminus$ co-generation fermentation tank, 
devices in 2007. The electricity consumption by the PSA is almost constant throughout the year. The electricity consumption for heating of the methane fermentation tank fluctuated very much. By the way, a practical scale methane fermentation process generally produces more electricity than it consumes. The energy balance must be positive at any biomass conversion plant. Although, we have purified the methane gas for several tests, the energy efficiency is higher in the direct co-generation from biogas than the cogeneration from $98 \%$ methane.

Table 2 shows various values on storage of methane and use by vehicles. The methane storage tank could have 25 times larger storage capacity by $0.6 \mathrm{MPa}$ of pressure and filler of special activated carbon ${ }^{2}$. The fixed type and mobile cylinder type methane gas filling devices functioned as designed. The forklift could store $8.1 \mathrm{Nm}^{3}$ methane in the tank of $162 \mathrm{~L}$, and operates the same as a gasoline vehicle.

\section{Operation and maintenance}

The YBP has been operated daily. We are arranging how much operation costs, the labor needed for operation \& maintenance, and what kind of maintenance and inspections that are desirable. Countermeasures for safety and sanitation are very important. We assigned four persons for normal operation and the research at the YBP. We spent $¥ 4,573,000$ for improvements and repairs, and $¥ 1,079,000$ for periodical maintenance and inspections in the 2007 fiscal year.

The long term operation \& maintenance plans are arranged in terms of inspections and exchange of parts ${ }^{2}$. For example, the methane fermentation process is estimated to require $¥ 3,660,000$ annually, the PSA $¥ 1,980,000$ annually, and the methane gas filling unit $¥ 10,000,000$ for ten years.

In this system, the assignment of roles and the sharing of costs for the collection and pretreatment of feedstock biomass, and the transportation and application of bio-liquid fertilizers are very important.

\section{Use of bio-liquid fertilizers}

The digested liquid is rich in nitrogen and potassium, low in phosphorus and includes various useful minerals. The handling of the digested liquid is not necessarily easy, and the transportation cost becomes expensive because of its low concentration. Therefore, we have developed technology to concentrate the digested liquid.

We produced and registered three types of bio-liquid fertilizer, namely, 1) digested liquid itself, 2) liquid phase of digested liquid using solid-liquid separation by coagulation (filtrated liquid), and 3) concentrated liquid of the filtrated liquid by RO membrane (RO concentrated liquid). Table 3 shows their components. The concentrations of T-N, $\mathrm{NH}_{4}$ $\mathrm{N}, \mathrm{T}-\mathrm{P}, \mathrm{T}-\mathrm{K}$, and TS of the digested liquid in 2007 were approximately 3,200 mg/L, 2,000 mg/L, $570 \mathrm{mg} / \mathrm{L}, 3,300$ $\mathrm{mg} / \mathrm{L}$, and 44,000 mg/L, respectively.

We have examined the above three types of bioliquid fertilizer for more than twenty crops/vegetables/fruit. The examination included transportation and application methods. Good cultivation results in both quality and yields were gained for example in spinach, komatsuna (Brassica campestris), cabbage, carrot, tomato, perilla, soybeans, rice, lotus, pear, and lawn grass.

\section{Key points of biomass refinery system}

This type of biomass refinery system will probably be practical if all processes operate smoothly. Buffer capacities of the plants/units/equipment are needed to overcome difficulties in the systematic operation. In terms of the total system of biomass use, the following seem to be very important: 1) sustainable management of regional resources, 2) to establish and maintain good relationships among the organizations concerned based on mutual reliance, 3) stable demand of produced materials/energy, 4) transportation and storage of biomass, and 5) application of reliable conversion technologies.

The challenge is to establish labor saving and economic methods for operation and management that can meet the seasonal fluctuations in the demand for produced resources. In terms of the digested liquid, the following are problems: converting it into a high value-added bio-liquid fertilizer;

Table 2. Storage of methane and its use by vehicles

\begin{tabular}{lccccc}
\hline \hline & Volume & Filler & $\begin{array}{c}\text { Pressure } \\
\left(\mathrm{kgf} / \mathrm{cm}^{2}\right)\end{array}$ & $\begin{array}{c}\text { Methane storage } \\
\text { volume }\left(\mathrm{m}^{3}\right)\end{array}$ & $\begin{array}{c}\text { Storage capacity* } \\
\text { (times) }\end{array}$ \\
\hline Storage tank & $20 \mathrm{~m}^{3}$ & activated carbon & 6 & 500 & 25 \\
Mobile cylinder & $120 \mathrm{~L}(30 \times 4)$ & - & 120 & $14.4(0.12 \times 120)$ & 120 \\
Pickup truck & $50 \mathrm{~L}(25 \times 2)$ & - & 120 & 6 & 120 \\
Forklift & $162 \mathrm{~L}$ & activated carbon & 9.9 & 8.1 & 50 \\
Yard operation vehicle & $75.4 \mathrm{~L}(37.7 \times 2)$ & activated carbon & 9.9 & 3.77 & 50 \\
Motorbike & $20 \mathrm{~L}(14+6)$ & activated carbon & 9.9 & 1 & 50 \\
\hline
\end{tabular}

Remarks: $10 \mathrm{kgf} / \mathrm{cm}^{2}$ (at) $=0.98 \mathrm{Mpa}$. ; *: methane storage volume/volume. 
Table 3. Components of bio-liquid fertilizers

\begin{tabular}{|c|c|c|c|c|c|c|}
\hline & Unit & $\begin{array}{l}\text { Digested liquid } \\
\text { 2005.9 } \sim 2006.12 \\
\text { average }(n=12)\end{array}$ & $\begin{array}{l}\text { Digested liquid } \\
2007.5 \sim 12 \\
\text { average }(n=5)\end{array}$ & $\begin{array}{l}\text { Filtrated liquid } \\
\text { 2005.9 } 2006.12 \\
\text { average }(n=9)\end{array}$ & $\begin{array}{l}\text { Filtrated liquid } \\
\text { 2007.5 } \sim 12 \\
\text { average }(n=5)\end{array}$ & $\begin{array}{c}\text { RO concentrated liquid } \\
2005.9 \sim 2006.12 \\
\text { average }(n=7)\end{array}$ \\
\hline Water content & $\%$ & 96.2 & 95.7 & 99.1 & 98.9 & 98.4 \\
\hline $\mathrm{pH}$ & - & & 7.7 & & 7.9 & \\
\hline $\mathrm{EC}$ & $\mathrm{S} / \mathrm{m}$ & & 1.89 & & 2.15 & \\
\hline MLSS & $\mathrm{mg} / \mathrm{L}$ & 20,974 & 31,800 & 393 & 252 & 716 \\
\hline MLVSS & $\mathrm{mg} / \mathrm{L}$ & 13,980 & 21,500 & 203 & 139 & 304 \\
\hline TS & $\mathrm{mg} / \mathrm{L}$ & & 43,600 & & 11,200 & \\
\hline VS & $\mathrm{mg} / \mathrm{L}$ & & 26,100 & & 2,500 & \\
\hline $\mathrm{COD}_{\mathrm{Mn}}$ & $\mathrm{mg} / \mathrm{L}$ & 16,400 & 13,000 & 1,149 & 1,033 & 2,167 \\
\hline BOD & $\mathrm{mg} / \mathrm{L}$ & 2,476 & 2,350 & 471 & 199 & 509 \\
\hline $\mathrm{TOC}$ & $\mathrm{mg} / \mathrm{L}$ & 6,029 & 4,160 & 810 & 709 & 1,446 \\
\hline T-C & $\mathrm{mg} / \mathrm{L}$ & 9,748 & 8,130 & 2,029 & 2,350 & 3,177 \\
\hline $\mathrm{Cl}^{-}$ & $\mathrm{mg} / \mathrm{L}$ & 1,202 & 1,790 & 1,041 & 2,040 & 2,116 \\
\hline $\mathrm{NH}_{4}-\mathrm{N}$ & $\mathrm{mg} / \mathrm{L}$ & 1,574 & 1,980 & 1,211 & 1,250 & 1,793 \\
\hline T-N & $\mathrm{mg} / \mathrm{L}$ & 3,386 & 3,230 & 1,297 & 1,400 & 2,580 \\
\hline T-P & $\mathrm{mg} / \mathrm{L}$ & 456 & 565 & 10.2 & 10.6 & 13.8 \\
\hline $\mathrm{PO}_{4}-\mathrm{P}$ & $\mathrm{mg} / \mathrm{L}$ & & 37 & & 4.61 & \\
\hline T-K & $\mathrm{mg} / \mathrm{L}$ & 3,018 & 3,280 & 2,066 & 2,990 & 3,649 \\
\hline $\mathrm{Fe}$ & $\mathrm{mg} / \mathrm{L}$ & 68 & & 9.3 & & \\
\hline
\end{tabular}

Remarks: The number of samples was different. The maximum number is represented. The blank boxes had no data.

developing new utilizations for bio-liquid fertilizers such as for hydroponics and for cultivation of energy crops; as well as developing efficient methods for transportation and application. It is necessary to work on the reduction of the environmental load by design of fertilization based on monitoring soil fertility and crops.

\section{Conclusion}

We have implemented research programs to demonstrate a pilot-scale biomass refinery system for suburban agricultural and livestock industrial areas. The achievements in terms of actual proof of total system including cooperation among related organizations and implementation of institutional necessary procedures, as well as engineering data accumulation that would contribute to making plans for the biomass town. The research program is still on going under the cooperation of many research organizations, companies, and government offices.

For sustainable use of biomass in a region, systemization of production, collection, transportation, storage, conversion, use of the converted biomass-derived materials/energy, and disposal is essential. Such promotions should be accelerated with cooperation among industry, academic society, administrations, and citizens. Systems for the biomass use should be involved in rural planning. Enforcement of biomass use projects needs to be promoted after adequate regional diagnosis in terms of materials/energy balance and stable demand of biomass-derived materials/energy. Not only economy at the biomass conversion plant but also positive externalities should be taken into account.

Achievements of this study provide a pioneering model for local governments all over Japan and other Asian countries to establish biomass towns employing local creativity and ingenuity.

\section{Acknowledgments}

We appreciate all project members of "Bio-recycle" and "Biomass Utilization Model" for their energetic efforts to get fruitful achievements. We would like to thank specially Prof. Akiyoshi Sakoda, The University of Tokyo, and Mr. Kunio Abe, Director of the YBP for their great contribution. We also thank Dr. Junji Takahashi, Director of NIRE for his overall suggestions as a team leader of the "Bio-recycle" project.

\section{References}

1. Government of Japan (2006) Biomass Nippon strategy. 1-28 [In Japanese].

2. Practical Systemization Unit-Chiba, Bio-recycle Project ed. 
(2007) Prologue to construct an agri-biomass town. National Agriculture and Food Research Organization (NARO), Ibaraki, Japan [In Japanese].

3. Sakoda, A., Mochidzuki, K. \& Yuyama, Y. (2006) Future prospects for biomass utilization system -Toward the holistic use of biomass resources (8)-. Nougyo doboku gakkaishi (Jour. of JSIDRE), 74(1), 53-58 [In Japanese].

4. Yuyama, Y. et al. (2006) Challenge to construct a biomass town. Nougyo doboku gakkaishi (Jour. of JSIDRE), 74(1), 7-10 [In Japanese].

5. Yuyama, Y. et al. (2006) Evidential study on a cascade use system of biomass in northeastern Chiba Prefecture of Japan. Proc. of Biomass-Asia Forum, Tokyo, 53-64.

6. Yuyama, Y. (2007) Evidential study of biomass use for activation of rural community. Syokuryo \& Anzen (Jour. of Food and Safety), 5(12), 32-39 [In Japanese]. 